\title{
Russian Borrowings in the Volga German Dialect in Russell County, Kansas
}

\author{
Maria Khramova \\ University of Kansas, 1445 Jayhawk Blvd., Lawrence, \\ Kansas66045,mascha20@gmail.com
}

Članek raziskuje nemško skupnost ob Volgi v okraju Russel v Kanzasu. Ponuja kratek pregled dialektoloških raziskav nemških narečjih ob Volgi v Kanzasu in analizira seznam ruskih izposojenk zbranih v Russelu leta 1913. Prispevek se ukvarja s sporno etimologijo nekaterih besed in izrazov ter razpravlja o leksikalnih pomenih s seznama iz leta 1913, ki so jih obdržali v narečju. Analiza dodatnih virov kaže, da so bile nekatere besede, ki so tradicionalno pojmovane kot ruske izposojenke ob Volgi, že sestavni del besedišča govorcev pred emigracijo, to pa pomeni, da so lahko izposojene tudi iz drugih slovanskih jezikov.

The present paper is based on a field investigation of the Volga German community in Russell County, Kansas. It provides a short overview of linguistic research, conducted on Volga German dialects in Kansas, and further analyses a list of Russian borrowings that was compiled in Russell in 1913. This contribution also addresses the disputable etymology of some words and expressions and discusses the lexical items from the list of 1913 that were retained in the dialect. Analysis of additional sources shows that some words that are traditionally treated as Russian borrowings acquired on the Volga may have been part of speakers' lexicon prior to emigration and could have been borrowed from other Slavic languages.

Ključne besede: nemško narečje ob Volgi, ruščina, jezikovni stik, dialektologija, otoški govor, prevzete besede, izposojenke

Key words: Volga German dialect, Russian language, language contact, dialectology, speech islands, borrowings 


\section{Introduction}

Fieldwork for the study of the Volga German dialect in Russell, Kansas started in May 2007 and lasted until March 2008. During this time, several trips to Russell were made and fourteen people have been interviewed. For the linguistic analysis, the number of informants had to be reduced to eight subjects, whose language proficiency ranged from relatively to very fluent.

This relatively small number of selected informants is explained by several factors. First, the total number of informants is limited by their age, since the community of Volga Germans residing in this area has undergone language loss, so that the last generation that remembers the language are senior citizens who have lived in this area since birth. Another difficulty lay in finding informants with sufficient language proficiency, as many brought English-speaking spouses into the community and abandoned their native language many decades ago. Linguistically proficient speakers were found through recommendations, even though they were not always successful, and recommended respondents could only remember isolated German words.

The selected informants were first or second generation Americans, three males and five females, with the age range from 73 to 90 years old at the time of the interview. They had similar levels of education ranging from incomplete high school to some professional training in addition to a high-school diploma. There were no drastic deviations in their social status - most of the subjects came from farmers' families and either continued their parents' business or acquired professions such as nurse, clerk, and a construction worker, thus belonging to the lower middle class of the society.

All subjects who participated in this study were born and raised in the Lutheran community of Russell County, Kansas, in and around the original settlement of Milberger, a town located in the southwest corner of Russell County, thirteen miles south of Interstate Highway 70 (I-70).

The history of Milberger began in 1876, when three men from the village of Kratzke (Počinnaja) left for the United States on July 12 to scout out land before moving their families to the unknown country. Traveling through Saratov, Hamburg, and New York, they arrived in Kansas City, from where they were first taken to Nebraska. Unhappy with conditions there, the committee was further driven by an agent from Lawrence to the land eleven miles south of Russell where seventy-two people from Kratzke eventually settled on October 5, 1876. Thus, a new Lutheran Volga German settlement, that later was named Milberger, appeared on the map. ${ }^{1}$

Map 1 illustrates that in the 1960s Milberger was a "quite important" Volga German settlement, whereas the town of Russell was labeled as "unimportant." Indeed, Russell was founded in 1871 by Irish emigrants, thus Germans were not the primary group that inhabited this town.

\footnotetext{
${ }^{1}$ Information about the first settlers was shared by Henry Bender in his article (1913).
} 


\section{GERMAN \\ SETTLEMENTS IN KANSAS}

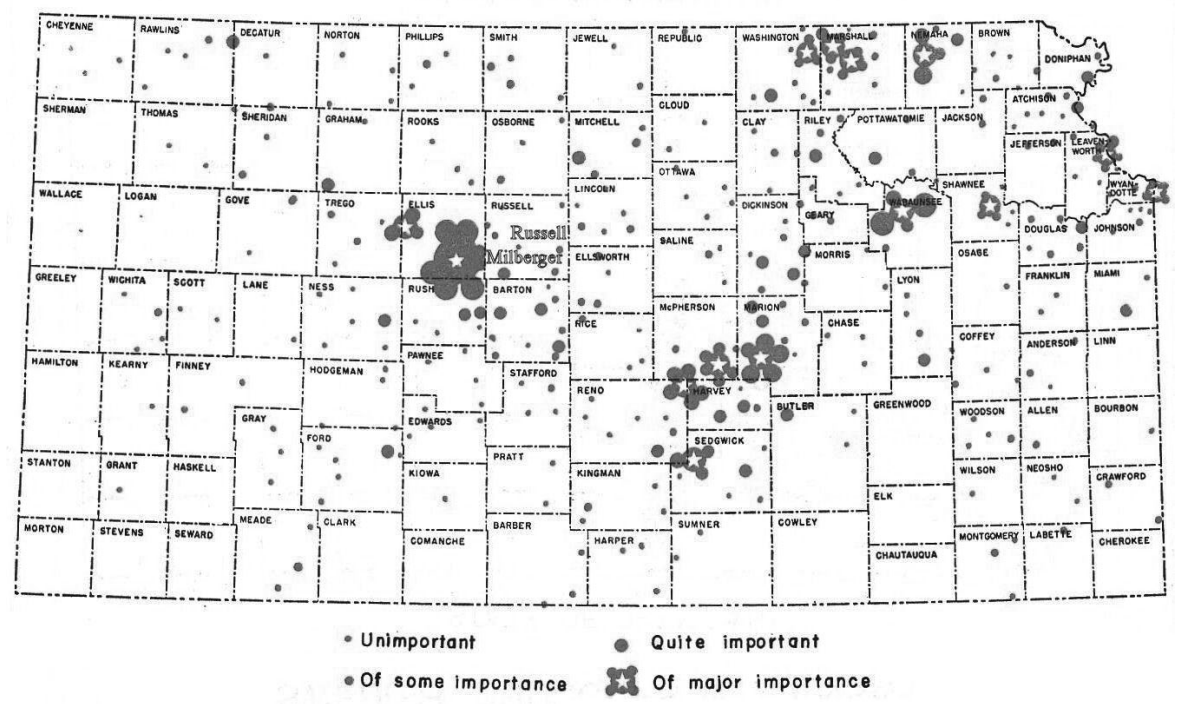

Map 1. German Settlements in Kansas (Carman 1962)

Milberger, on the other hand, was founded as a Volga German colony that had no other ethnic groups living in it for the first few decades. Most inhabitants of Milberger and Russell were neighbors or relatives who arrived in the United States from the same Volga villages, so these two colonies "grew into each other and expanded north and west" (Sallet 1931: 35).

\section{Research on Volga German Dialects in Kansas}

The first attempts to explore Kansan Volga German dialects linguistically were made by J. C. Ruppenthal in 1913. He was interested in the Volga German community that resided in his hometown of Russell, Kansas, so he wrote articles about the history and language of these people. The linguistic description of the dialect was limited to a general note on its Hessian origin; however, a list of Russian borrowings that he collected comprised an important part of his work.

In the 1950s and 1960s, J. Neale Carman conducted fieldwork throughout Kansas, exploring non-English speaking communities of the state. His unpublished papers with notes, newspapers, and letter exchanges are preserved at the Spencer Research Library (University of Kansas) and include several boxes filled with alphabetically organized folders. Carman travelled to Russell County several times and visited Milberger, Russell, Dorance, and Bunker Hill. His notes provide important information about the language situation in this Volga German community in the 1950s and in the 1960s. 
Large Catholic Volga German settlements in Ellis and Rush Counties, Kansas have drawn the most attention of dialectologists in the years following Carman's publications. An extensive research of these dialects at the University of Kansas started in early 1980's (Keel 1981, 1982, 1989, etc.). Several term papers, master theses, and a dissertation (Johnson 1994) written by students at the German Department in the 1980s and the 1990s contributed to the field of Volga German dialects research by providing their detailed linguistic description and saving samples of these languages on tapes. The Lutheran Volga Germans in Russell County, Kansas remained the only group that has never been investigated. Ruppenthal's list of Russian borrowings was the only study conducted on language of Volga Germans of Milberger and Russell.

\section{Russian Borrowings in the Milberger dialect}

The conservative community of Volga Germans has always been very reluctant about allowing foreign influences into their lives. Having adjusted to the "external circumstances" such as the dressing habit or food preferences of their new neighbors, Volga Germans tried to keep their religion, traditions, and language free of foreign influences. However, they could not avoid picking up some words and expressions from their Russian neighbors.

As remarked by Johnson (2001), the research that was carried out in Kansas at the beginning of the twentieth century was limited to compiling word lists by people interested in the history of their hometowns, who at the same time lacked a linguistic background. Thus, the available information will neither give us "a full picture of the use of Russian loanwords in the Volga German dialects, either in Russia or in Kansas," nor provide us with "enough material to be certain that any conclusion we might make about why words were retained or lost are true" (Johnson 210).

The earliest list of Russian words in the Volga German dialect in Kansas appeared in $1910^{2}$ in an article by Rev. Francis S. Laing, in which he mentioned eleven Russian words that he collected from his informants: ambar 'granary', arbus 'watermelon', galoš 'galosh', kabak 'wages', kaftan 'coat', kalač 'white bread', kalunč 'swing', kardus 'cap', plotnik 'carpenter', polšupka 'large overcoat', prostoj 'common' (522).

A longer list from the year 1913 was compiled by J.C. Ruppenthal, a judge from Russell, Kansas. This list contains a total of forty eight lexical items with some words of obvious French origin. Seven out of eleven words from Laing's list are also mentioned by Ruppenthal, sometimes with a different spelling.

For researchers, investigating Russian borrowings in the Volga German dialects of Kansas, Rupenthal's list became a basis for questionnaires. Un-

${ }^{2}$ The first immigrants from Kratzke came to Russell, Kansas, in 1876; the second big wave was during the years 1900-1910. 
fortunately, he had no linguistic training and did not provide any information either about the background of his informants (such as their age, religion, place of birth, etc.) or about the places where these words were collected. ${ }^{3}$ It is also not clear whether this list was obtained by the direct questioning of informants concerning what Russian words they knew or actively used or by listening in and making notes. If the former approach was used, that would mean that speakers were aware of which words in their language were of a foreign origin. Unfortunately, it was not always the case with the first and second generation speakers who were the subject of this study. Since Russian words barely occur in the free speech, this unawareness could have been a problem for identifying those words if Ruppenthal's list did not exist.

The Russian words collected by Ruppenthal were published in 1913 in his article The German Element in Central Kansas and in 1914 in a one page article Russian Words in Kansas. The later edition (1914) was surprisingly missing half of the words, but appended Russian translations and etymological comments.

The first column in the following table shows the full list of forty-eight Russian borrowings, as it was published in 1913 with the original orthography. ${ }^{4}$ The second column provides English equivalents of these words, as they were translated by Ruppenthal. Russian translations in the third column come from the article of 1914, if they are marked with an asterisk. Those words that were missing in the 1914 publication (and are marked by the sign ${ }^{\text {a) }}$ ) were translated by the author.

\begin{tabular}{|c|c|c|c|}
\hline & 1913 & English translation (1913) & Russian word (1914) \\
\hline 1. & ambar & granary & ambar \\
\hline 2. & arbus, erbus & watermelon & arbus \\
\hline 3. & baldo, paletot & overcoat & palto* $^{*}$ \\
\hline 4. & bantke & glass jar & banka* \\
\hline 5. & betta! & awful! (exclamation) & beda!* \\
\hline 6. & bollschupke & short overcoat & polušubok* \\
\hline 7. & brosch & $\begin{array}{l}\text { land that was once cultivated but } \\
\text { gone back to grass }\end{array}$ & $\begin{array}{l}\text { broš*, from brosat', to } \\
\text { abandon } \\
\text { *brošennyj }\end{array}$ \\
\hline 8. & galosche & overshoes of rubber or leather & $\begin{array}{l}\text { galoša*, Sg } \\
\text { galoši*, } \mathrm{Pl} \\
\text { galoš }{ }^{\mathrm{a}}, \mathrm{Gen} . \mathrm{Pl} .\end{array}$ \\
\hline 9. & gas & petroleum, also its products & gas* \\
\hline
\end{tabular}

${ }^{3}$ His native town of Russell is the most probable place, but he might have covered an extended area for his research.

${ }^{4}$ Whereas words in the first column preserve the original orthography used by Ruppenthal, Russian forms in the third column are spelled according to the modern linguistic transliteration system of Russian words. Further, Russian borrowings in the Milberger dialect will be spelled using Ruppenthal's orthography. 


\begin{tabular}{|c|c|c|}
\hline 1913 & English translation (1913) & Russian word (1914) \\
\hline 10. gofta & short jacket for women & kofta \\
\hline grulitz, gruelitz & a small closed porch & kryl'co* \\
\hline 12. $\begin{array}{l}\text { gumia, gumja, } \\
\text { gumya }\end{array}$ & partner, pal, pard (comrade) & $\begin{array}{l}\text { kum*, } \mathrm{Sg} \\
\text { kumja*, } \mathrm{Pl}\end{array}$ \\
\hline 13. jemtschik & driver of a vehicle & jamščik* $[j e]$ \\
\hline 14. kalotsch & $\begin{array}{l}\text { loaf of white bread baked in a big } \\
\text { outdoor oven }\end{array}$ & kalač*, $\mathrm{Sg}$ \\
\hline 15. kardus & $\begin{array}{l}\text { a cap probably from Carthusian } \\
\text { garb }\end{array}$ & kartuz $[s]$ \\
\hline 16. klapot & $\begin{array}{l}\text { a lawsuit; hence, any trouble. The } \\
\text { word is used in the pl. to mean } \\
\text { lawsuit or trouble. The partitive } \\
\text { genitive is commonly used in the } \\
\text { Russian idiom. The Germans did } \\
\text { not recognize the construction } \\
\text { and so borrowed that form as the } \\
\text { simplest and most familiar. }\end{array}$ & $\begin{array}{l}\text { xlopoty } \\
\text { gen. pl. xlopot }\end{array}$ \\
\hline 17. knout & whip & knut \\
\hline 18. konieren & $\begin{array}{l}\text { to torment, to ill treat a sentient } \\
\text { being (French, counieren) }\end{array}$ & --- \\
\hline 19. manischka & $\begin{array}{l}\text { shirt with (starched or) ironed } \\
\text { bosom }\end{array}$ & maniška \\
\hline 20. manschetten & cuffs on shirt & manžety* \\
\hline 21. messit & $\begin{array}{l}\text { bran and straw mash for feeding } \\
\text { live stock }\end{array}$ & $\begin{array}{l}\text { mesivo, from mesit'* } \\
\text { to knead }\end{array}$ \\
\hline 22. natschelnik & a kind of court officer & načal'nik \\
\hline 23. ninatte & a negative, as by "no means" & $\begin{array}{l}\text { (possibly) ne nado } \\
\text { or } n i z a \text { c to }\end{array}$ \\
\hline 24. nubi & $\begin{array}{l}\text { a part of apparel, perhaps a } \\
\text { fascinator }\end{array}$ & (?) \\
\hline 25. pachschu & $\begin{array}{l}\text { a garden plot, (or similar small } \\
\text { patch of cultivated ground) } \\
\text { (a garden plot for watermelons)* }\end{array}$ & baxča \\
\hline 26. papyrus & cigarette & $\begin{array}{l}\text { papirosa, } \mathrm{Sg} \\
\text { papiros, } \mathrm{Gen} . \mathrm{Pl} .\end{array}$ \\
\hline 27. parschol & go away! & pošël, pret. of pojti \\
\hline 28. parscholista & go away! & $\begin{array}{l}\text { Originally in the article: } \\
\text { "pozhalujsta, for pozhaluj, } \\
\text { imper. of pozhalovat", } \\
\text { to grant, plus the suffix } \\
\text {-sta. Lit. grant, please. } \\
\text { A formal way to request } \\
\text { anyone to be gone." } \\
\text { "pošël otsjuda"a }\end{array}$ \\
\hline 29. plet & a wide whip or riding quirt & plet' \\
\hline
\end{tabular}




\begin{tabular}{|c|c|c|c|}
\hline & 1913 & English translation (1913) & Russian word (1914) \\
\hline 30. & plodnik & a carpenter & plotnik \\
\hline 31. & preciz & precise & --- \\
\hline 32. & pressiert & pressing & --- \\
\hline 33. & presumieren & presume & --- \\
\hline 34. & radnik & recruit & ratnik \\
\hline 35. & rendezvous & rendezvous & --- \\
\hline 36. & samovar & tea steeper or self-cooker & samovar \\
\hline 37. & sarai & $\begin{array}{l}\text { a small building to a house, but } \\
\text { disconnected }\end{array}$ & saraj* \\
\hline 38. & scharmand & $\begin{array}{l}\text { pretty; fine garment; considerable } \\
\text { in amount }\end{array}$ & --- \\
\hline 39. & sedilka & $\begin{array}{l}\text { bridge or back band on harness } \\
\text { for draft animals (on harness of } \\
\text { horses) }\end{array}$ & sedëlka \\
\hline 40. & simlinka & $\begin{array}{l}\text { a dugout (a cave or dugout to live } \\
\text { in or use as a dwelling) }\end{array}$ & zemljanka \\
\hline 41. & sotnik & a constable & sotnik \\
\hline 42. & steppe & prairie & step $^{\prime}$ \\
\hline 43. & stuft & a measure of about a quart & Germ. Stoff* \\
\hline 44. & tulup & a garment; a greatcoat & tulup \\
\hline & tuppke & leggings; felt shoes & $\begin{array}{l}\text { tapok* } \mathrm{Sg} \\
\text { tapki* } \mathrm{Pl}\end{array}$ \\
\hline 46. & verkolumpieren & lapsus linguae; slip of tongue & --- \\
\hline 47. & vergallopiren & slip of tongue & --- \\
\hline 48. & winna & a plant like wild morning glory & vjun, vjunok* (?) \\
\hline
\end{tabular}

Several points need to be addressed in regards to the table above:

\subsection{Phonological adaptation}

The phonological adaptation of Russian loan words shows the following peculiarities:

- In a word's final position, devoiced consonants occur in the same way as in Russian: kardus (kartus), gas (gas).

- Voiceless consonants in initial position and in consonant clusters next to a sonorant are lenited: baldo (pal'to), bollschuppke (polushubok), gofta (kofta), grulitz (kryl'co), gum (kum), plodnik (plotnik), radnik (ratnik), kardus (kartus).

- The traditional Russian ending - $a$ for feminine nouns is either kept in the original form: gofta (kofta), manischka (maniška), sedilka (sedëlka), semlinka 
(zemljanka) or replaced with the German noun ending -e (partial reduction of the vowel): bantke (banka), galosche (galoša). Words polušubok and step' also receive the ending in the dialect: bollschupke, steppe.

- As mentioned in research on Russian loans (Wiens 99, Blokland 499), some words are borrowed in a non-nominative form due to a high frequency of oblique cases occurring in a conversation. So, the word klapot (Rus. xlopoty - nom. pl) could be borrowed from the gen. pl. Rus. form xlopot [hlapst], since it occurs more frequently in the word combinations mnogo xlopot ("a lot of trouble") or stol'ko xlopot! ("so much trouble!"). A similar pattern could have been followed while adopting the word papyrus (Russ. papirosa) which corresponds with the Russian gen. pl. form papiros and occurs in frequent phrases like "do you have any cigarettes?" ("u vas net papiros?", "papiros ne najdëtsja?", etc). ${ }^{5}$ The word baxča is borrowed in an unexpected form pakhschu, which could be attributed to the acc. sg. baxču heard by the settlers in word combinations like "you see (the plot)", "you need to get (a plot)", and others. It is not clear if tuppke designates singular or plural in the dialect but it is closer to the Russian plural form for "slippers" - tapki (tapok - nom. sg.).

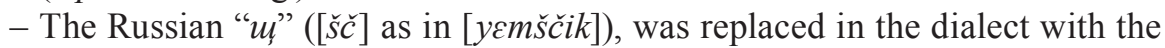
affricate "c", familiar for the dialect speaker - jemtschik.

- Vowel substitutions occurred both in stressed and unstressed syllables: ${ }^{6}$ a. raising in stressed syllables: Russ. kaláác $\rightarrow$ Germ. dial. kalotsch, Russ. načál'nik $\rightarrow$ Germ. dial. natschelnik, Russ. sedëlka $\rightarrow$ Germ. dial. sedillka, Russ. zemljánk $a \rightarrow$ Germ. dial. semlinka; Russ. papirós $a \rightarrow$ Germ. dial. papy$r \underline{\underline{u}} s ;$ b. rounding in unstressed syllables: Russ. $k r \underline{y} l$ 'co $\rightarrow$ Germ. dial. grulitz. - Syntagmatic changes include epenthesis: Russ. pašël $\rightarrow$ Germ. dial. parschol or parscholista; Russ. banka $\rightarrow$ Germ. dial. bantke; Russ. kryl'co $\rightarrow$ Germ. dial. grulitz and syncope: Russ. polušubok $\rightarrow$ Germ. dial. bollschupke, polschupka (in Laing).

\subsection{Questionable etymology of selected words}

All Russian forms without the $(*)$ come from the 1914 article edited by Chace and were provided by "a Russian couple (Mr. and Mrs. Shapovalov, of the University of Maine)" (161).

- One word on this list has an arguable explanation of origin: Germ. dial. parscholista for "go away!" is linked to the Russian word požalujsta 'please': "pozhalujsta, for pozhalui, imper. of pozhalovat', 'to grant', plus the ending

\footnotetext{
${ }^{5}$ However, this might also be attributed to the traditional vowel reduction at the end of the noun typical for Russian words borrowed by the German dialect speakers.

${ }^{6}$ Vowels in the first syllables of words like Russ. jamščik, xlopot (gen. pl.), zemljanka are pronounced as $[\varepsilon],[a]$, [i] respectively, so they were borrowed in their spoken form by the dialect speakers, and thus have no vowel change.
} 
-sta. Lit. grant, please. A formal way to request anyone to be gone" (161). Most likely, this connection was made by the Russian couple solely based on the phonetic similarity, since the expression "go away!" could barely be related to the word please. Their last remark that požalujsta may be used as "a formal way to ask anyone to be gone" was rather a desperate attempt to explain this connection, since as the English please and the German bitte, the Russian požalujsta can be used as an invitation to any kind of action depending on the context of a given situation (to sit down, to start doing something, to come in, to go away, etc.). It is more likely that porschalista is a folk etymology, connecting it to the form of the Russian expression pošël otsjuda! ('go away!').

- Three words from the first list appeared to be difficult to link to any Russian word - ninatte 'by no means', stuft 'a measure of about a quart', and nubi 'item of apparel', (probably a fascinator). Possibly, ninatte could be related to the Russian ne nado 'don't!' or ni za chto 'by no means'. The word stuft most probably is the originally German word Stoff (Stauf) that was also used in the Russian language as a measure of 1.23 liter. The Russian equivalent to the word $n u b i$ is unknown. It can be a procope form of a longer Russian word.

- The words winna 'bindweed' and brosch 'uncultivated land' can be either borrowings from Russian (Russ. vjun and brošennyj 'abandoned' or German dialectal forms coming from Winde and Brache. The origin of the word kaluntsch 'swings' from Laing's list is more likely connected to the German dialectal form klunsch than to the Russian word kačeli.

- Elimination of the words like konieren, manschetten, preciz, pressiert, rendezvous, scharmand, verkolumpieren, vergaloppiren from the later publication of the Ruppenthal's list is understandable since their French origin is apparent, even though some of them might have made their way into the Volga German dialect in Russia. For comparison, charmant and manschetten are registered in Grimm's Deutsches Wörterbuch whereas rendezvous is not. Another word from this category is bedell (Russ. butyl" "bottle"), which was found in our data but was not on Ruppenthal's list.

\subsection{Primary or Secondary Borrowings?}

Another problem arises if one needs to determine whether the words traditionally treated as Russian loans in Volga German dialects are primary (borrowed while in Germany from Slavic languages or French) or secondary loanwords (borrowed while staying in Russia). As examples, one can take words baldo, galosch, gofta, and kardus. The word baldo comes from the French paletot "overcoat", so it could have been borrowed by the settlers along with other French words in the $17^{\text {th }}$ century back in their homeland. However, the phonological adaptation of the word with the lenition of voiceless consonants typical for Russian borrowings in German (Russ. pal'to - Ger. baldo) as well as its absence in Grimm's dictionary could be indirect proof for it being borrowed in 
Russia. This word has also been traditionally classified as a Russian borrowing in Baltic languages, a view that Blokland does not support (2005).

The controversy with the first three words (galosch, gofta, kardus) is that they are seen as German borrowings in the Russian Etymological Dictionary by M. Fasmer. The same dictionary mentions that kardus was possibly introduced by the Volga German colonists into the life of a Russian farmer:

а. "галоша - borrowing from Germ. Galosche which came from Fr. galoche..." (389) b. “кофта - ... Because Swed. kofta, Dan. kofte, Norw. kufta could not be borrowed from Russian, we should rather assume the Western origin of the Russian word. ... The origin of Slav. and Scand. words is possibly the Low Germ. Bremen kuft (man's long outer garment (caftan) of coarse cloth), Balto-Germ. kuft (a house coat)." (355)

с. “картуз - ... From Fr. cartouche borrowed from It. cartoccio. ... Sobolevskiy ... assumes that картуз is of the Dutch origin (holl. kardoes); same in Mölen $(91,141$...). It is being pointed out that kardus was brought over by the German colonists to the Volga and was spread among Russian farmers (Melnikov 3, 141)" (204)

Despite Fasmer's explanations, gofta $(=k u h t i)$ is treated as a Russian borrowing in Baltic German by Kiparsky (1936: 162-163) and in Estonian by Blokland (2009: 190). Apart from that, Grimm's German Dictionary has no record of the words kuft, kufter, gofta or any other form of it. On the other hand, the word koffter is considered to be a Polish borrowing found in German documents (Urkunden) produced by the German Kanzlei in Krakow (Kaleta 1999: 71). Thus, all sources except for the Russian Etymological Dictionary, point at the Slavic origin of this word in German dialects. In the case of the Volga German word gofta, its close resemblance with the Russian word, rather, points to its Russian origin.

Grimm's dictionary provides no entry for the word galosche, whereas entry on "karduse" does not mention it in a sense of a "cap":

"karduse - die kanonepatrone, pulverbeutel zur kanoneladung. nl. kardoes. aus fr. cartouche, das später als kartusche neu aufgenommen war" (1873: 23).

Indirectly, it suggests the absence of these words in German language by 1870s.

\subsection{Russian Loanwords in Baltic German}

The lists of Russian borrowings in Baltic German and Estonian adduced by Kiparsky and Blokland shows that $42.5 \%$ of the words from Ruppenthal's list (seventeen out of forty words, if we exclude the eight clearly French items) were documented as Russian loanwords in Baltic German and/or Estonian. The table below shows the Volga German word in the first column with its variant in Baltic German (as documented by Kiparsky and by Blokland). The third and the fourth columns provide the year when this word was first documented in Baltic German and in Estonian, respectively. 


\begin{tabular}{|c|c|c|c|}
\hline $\begin{array}{l}\text { Volga German } \\
\text { (Milberger) }\end{array}$ & $\begin{array}{l}\text { Russian loans in } \\
\text { Baltic German }\end{array}$ & Year & Estonian \\
\hline ambar & ambare & 1779 & 1893 \\
\hline arbus & arbuse (?) & & $\begin{array}{l}1869 \text {, loan from either Baltic } \\
\text { Germ. or Russian. }\end{array}$ \\
\hline baldo & & & $\begin{array}{l}\text { mistakenly seen as a Russian } \\
\text { word }^{7}\end{array}$ \\
\hline gofta & kuft & 1776 & 1869 kuhti \\
\hline jemtschik & jemtschik & 1795 & \\
\hline kalotsch & kalatsche & 1795 & 1869 \\
\hline klapot & chlopott (klapott) & 1889 & \\
\hline knout & knute & 1795 & 1869 \\
\hline pachshu & & & bahtša, 1960 \\
\hline papyrus & & & pabeross, 1893 \\
\hline parschol & $\begin{array}{l}\text { poschol! (fahr los! } \\
\text { fort!) }\end{array}$ & 1880 & 1956 \\
\hline plet & plette & 1936 & 1869 \\
\hline plodnik & plotnik & 1795 & 1818 \\
\hline sarai & & & sara, sarrai, 1869 \\
\hline sedilka & sedulke & 1795 & 1869 \\
\hline sotnik & $\begin{array}{l}\text { sesnycken, sesnicke, } \\
\text { sostenicken }\end{array}$ & 1495 & 1869 \\
\hline tulup & tolubbe, talubbe & $\begin{array}{l}1785 \\
\text { probably } \\
\text { from Polish }\end{array}$ & 1893 \\
\hline
\end{tabular}

Several words that are not on Ruppenthal's list but have been found in Russell and Ellis County (both in Kansas) as well as in the WDSA also appear in Baltic German and/or Estonian.

\begin{tabular}{|l|l|l|l|}
\hline VG & Baltic German & Year & Estonian \\
\hline birog & piroge & 1785 & 1869 \\
\hline blina & blinis & 1880 & 1933 \\
\hline kabak & kaback(e) & 1643 & \\
\hline kaftan & & & kaftan, 1869 \\
\hline kvas & kwas & 1795 & 1933 \\
\hline nuzhnik & & & first half of the $20^{\text {th }}$ century \\
\hline prostoi & prost, prostoi & 1795 & \\
\hline
\end{tabular}

${ }^{7}$ Blokland adds baldo to the words that are mistakenly treated as Russian borrowings by other authors. He does not give an explanation, but it is most likely because he sees this word as a French borrowing. 
At least four words from these lists were also known in German territories, as was concluded by other researchers. The word Kaftan is recorded in Grimm's Dictionary and appears in the documents of the Chancellery of Krakow in the $16^{\text {th }}$ century (Kaleta 1999: 72), as well as the word Koffter (gofta in Russell) (Kaleta 1999: 71). The word kalatsch (white bread) was introduced in the German territories in the $17^{\text {th }}$ century through the contacts encouraged by the Hansa trade union (Winter 1961: 275). Kaback or kabacke is described as being "wide spread in German dialects" but the original Russian meaning Wirtshaus (tavern) was only documented for Baltic German (also attested with this meaning in Victoria, Kansas). In other German dialects that borrowed this word (Pomerania, Silesia, Upper Saxony, Westphalia), it means "old shabby house" (Bielfeldt 1965: 16; Winter 1961: 273) which could have developed from "old tavern". Besides, the words knut and steppe are assumed to be borrowed in the $17^{\text {th }}$ and $18^{\text {th }}$ century, respectively, from the Russian language into the German Schriftsprache (Bielfeldt 1965: 16).

These data show that many of the words known on the Volga have been documented not only for the Baltic German (mostly at the end of the $18^{\text {th }}$ century, some even as early as in the $15^{\text {th }}-16^{\text {th }}$ century), but also for other German dialects in the $16^{\text {th }}-18^{\text {th }}$ centuries. This does not mean that any or all of these borrowings were known to the first settlers before they arrived in Russia. The available records of the first settlers of Kratzke show that two families came there from Finland, one came from Poland, and several arrived from Central parts of Prussia (Pomerania, Brandenburg) (Pleve 1998: 382-390). They could have brought some Slavic borrowings with them (including words like tulup and prostoj that some see as Polish loan words), but it is hard to say with certainty if that was the case. The only conclusion that can be made is that all the facts discussed above suggest that the amount of Russian influence on the Volga German dialects could be narrowed down to even fewer lexical items.

\section{Retained Russian borrowings in Milberger dialect}

Ruppenthal's list was used as the basis of the questionnaire presented to the subjects of this study, including all obviously French words for the sake of completeness. It was expanded by additional words taken from Laing and Wiens that were missing in Ruppenthal's data. Work with this survey constituted a portion of the interview when informants were asked whether they recognized the word and if they used it actively. In addition, participants were asked if they recognized random words from the long Dinges' list. Interviews showed that the number of Russian words retained in the vocabulary of the speakers is scarce.

Out of eight subjects, all eight recognized or mentioned words arbus, nuzhnik, schtepp, birog, blini (blina), sarai (sairai), gum-gumja, grilitz (grilitzje), babushka, and ambar. Two people knew the words gofta, matschka, and trosti/schtrasti. Words galatsch, samovar, and kvas were remembered by one 
person each (though not the same person). Three people recognized the word scharmand.

Several of these borrowings need to be discussed in detail.

- Some words that informants perceived as Russian turned out to be dialectal German words. One informant mentioned that they used several different words to call a fly such as flieche, schnouk, and mukk. She thought that some of them had to be of Russian origin. At the first glance, mukk sounds similar to the Russian muxa but, in fact, mugg is a common word for a fly in German dialects.

- The word scharmand, even though not a Russian borrowing, is worth mentioning because of an interesting development it underwent in the dialect. In Grimm's dictionary, this word is recorded with its original French meaning

"charmant - pretty, charming" and additionally "loved": "bellus, venustus, mit voll auslautendem $\mathrm{t}$ : der mensch ist ganz charmant; mein charmanter, mein geliebter; die charmante, die geliebte; charmante seele! Felsenb. 2, 344; er hat ihr einen charmanten brief geschrieben. (Bd. 2).

- In the discussed dialect, this word developed the meaning "pretty" in the sense of "quite, rather": es is scharmand schen draos 'it is quite nice outside', der hat scharmand viel geld 'he has quite a lot of money'; sie is scharmand schen 'she is quite pretty', wie geht's? - scharmand gut 'how are you?' 'pretty good'. Apparently, this shift in the meaning occurred not in the United States but in the Volga region since it is also mentioned in Berend (2003: 251) as schamant meaning ziemlich gut and in Heinz (2006: 141).

- Sarai or sairai (as most of the informants pronounced it) is a word that Ruppenthal or/and his informants perceived as a Russian borrowing meaning "storage building" that is also metaphorically used for "a mess" (both meanings are common in Russian, as well). All informants in Russell knew this word primarily in the second meaning (na, die hen sarai dehin gmocht 'they made a mess there') and were surprised to hear that it was a Russian word. The common reaction was: "I would always think of pigs when I heard it" (the word for pigs in this dialect is $\underline{s} a i$ ). Since some informants confirmed that the same word was used for a "storage building", most probably, sarai was borrowed from the Russian language and then linked to the German dialectal word sai by folk etymology, as in the standard German Sauerei ("mess").

- In the dialect, some words exist in various forms. For example, bliny (same form as in Russian) and blina; grulitz and grulitzje (with the diminutive suffix). The word gum/gumja shows even more variations. Some speakers preserve the original Russian distinction between singular (gum) and plural (gumja). Others use the word gumja as a singular form (des is main gumja 'this is my pal'), while for one informant gumja was a diminutive form of gum with the meaning "little pal."

- Some words were recognized by the speakers with the remark that some older relative used to say it, for example the word gofta that one informant recalled with a comment "grandpa used it [for a short coat]". 
- The word trosti was not originally in the questionnaire but during the very first interview one informant asked if this word that her mother remembered hearing from her mother was a Russian word. According to this subject, trost $i$ was used both for "hello" and for "see you around" (similar to the Hawaiian aloha, as she put it). Another informant only knew it as a greeting in a form schtrasti which is closer to the Russian original (zdrasti). Even though both informants were from the same generation and knew each other from childhood, according to the second subject, this form was a rather common greeting to use among close friends "for being silly instead of hello": $n a$, schtrasti! schon lange net ksehe 'oh, hi! long time no see!'. Apparently, the usage of certain words was unequally spread within the community.

- The word matuška ("little mother") was on the additional questionnaire, but it was not recognized by subjects during the first interview when words were read out loud. Instead, one informant asked later that day, if the word mačka was Russian. Her mother-in-law, when she wanted to say something like "you are a character!" to her little granddaughters, would say du bist ne mačka! Further the informant added, for endearment, her mother-in-law also said "du, mačert," "so kleine mačert," which can be another derivative from the Russian word mat', mater' 'mother'. Mačka was recognized by one more informant who described the meaning of "oh, du mačka" as "you silly thing!' used for little girls only. An informant form the Catholic settlement of Victoria, Kansas knew this word with the meaning "Russian woman, mamma" (Die alt Russe-Matschka laaft in Dorf rum). Etymologically, the word mačka is most probably linked to the Russian word matuška, but there is a possibility of it being related to the word mačka ('cat') that exists in several Slavic languages, if speakers borrowed it before emigrating from Germany. - The fact that some words are only remembered as being said by parents or grandparents proves that the amount of Russian loan words was more extensive. The lexical items that remained in usage of this last generation of speakers were names of foods (birog, bliny, arbus, kalatsch), buildings or sights around the house (ambar, nuzhnik, grilitz, sarai, schtepp), and frequently used or heard words (sairai for "mess" or gum). An interesting fact is that the group of words that almost completely vanished were clothing items (bollschupke, baldo, kardus). Partly, they have been replaced by the English words (baldo $\rightarrow$ coat) with the word mondl being used only for a pastor's coat. Similar to the pair baldo $\rightarrow$ coat, many lexical items show a trend described in Berend (2003: 258): If a word was known only as a Russian borrowing on the Volga, it was replaced by an English word in America, without a German equivalent being known to the speaker: siren $\rightarrow$ lilac bush, badnos $\rightarrow$ tray, plet, knut $\rightarrow$ whip, bollschupke $\rightarrow$ overcoat, konfarge $\rightarrow$ (stove) burners, čulan $\rightarrow$ pantry, plodnik $\rightarrow$ carpenter, guljanka $\rightarrow$ party, etc.

The total number of words in the main questionnaire was 53; in addition, random words were asked from Dinges' extensive list. This additional ques- 
tionnaire did not bring results when it came to the recognition of new words ${ }^{8}$. However, it helped to detect the trend of Russian words being replaced by the English equivalents with no corresponding German words being present in the lexicon of the dialect speakers.

Most Russian loans were recognized by speakers during the work with questionnaires; however, some of these words came up in free speech when informants were talking about their eating habits (birog, bliny, arbus ${ }^{9}$ ) or when describing pictures with rural scenes or farmer's life (ambar, grulitz, sarai, schtepp).

The total of $30 \%$ (16 out of the 53 words, including borrowings of French origin) or $36 \%$ (if French words were excluded) were recognized by the informants, whereas just 10 words $(20 \%$ or $22 \%$, depending on whether or not the French words were counted) were recognized by all speakers. Similar statistics can be seen in the study of the Catholic Volga Germans in Ellis County conducted by Johnson who also used Ruppenthal's list as a questionnaire (1996: 79). Speakers from Ellis County recognized 17 out of the 51 presented words (33\%).

These statistics show how fast borrowed words can vanish from a given language due to a set of linguistic and extralinguistic reasons, such as language economy or relative infrequency of some words (which often can lead to their replacement by new loans), as well as change of a dominant language surrounding the community, cultural pressure from of the outside, and disappearance of designated concepts.

\section{Conclusions}

The Volga German community in Russell, Kansas first started in 1876 and expanded through new waves of immigrants in the 1900s-1910s. The German dialect that was spoken in this area was first investigated in the 1910s, when some fifty words were documented as Russian borrowings presumably acquired by speakers of this dialect on the Volga.

Some words from the list compiled in 1913 by Ruppenthal were of questionable origin (winna, brosch, stuft, nubi) and some were definitely French borrowings (konieren, manschetten, preci, presumieren, pressiert, rendezvous, scharmand, verkolumpieren, vergallopiren). Other words that have traditionally being treated as Russian loans acquired during a century and a half long stay on the Volga could have been known in some German territories before speakers emigrated to Russia. Examples of Russian borrowings in Baltic German, as well documents by German chancelleries, demonstrate that some words could

\footnotetext{
${ }^{8}$ Just one word (kvas) from the longer list was recognized by single informant.

${ }^{9}$ A culinary specialty of this community is a so called schlekselkuche, a cake baked with watermelon preserves, thus a frequent occurrence of the word arbus in the description of eating habits.
} 
have been borrowed prior to the Volga emigration from Russian or even other Slavic languages.

A century after the list of Russian borrowings in the dialect in question was compiled, $65-70 \%$ of the words from the Ruppenthal's list were no longer recognized by informants who belonged to the last generation of dialect speakers. ${ }^{10}$ Moreover, several lexical items that some speakers recognized were remembered as not being actively used, but rather heard from parents or grandparents (gofta, matchka, trosti).

The disappeared Russian words had no German equivalent in speakers' vocabulary, so they were replaced with English loans (baldo-coat, bantke - jar, klapot-troubles, knout-whip, natchelnik-boss, papyrus - cigarette, etc.) or fully disappeared as anachronisms (bollschupke, jemtschik, kardus, manischka, radnik, samovar, sedilka, simlinka, sotnik, etc.). The sixteen Russian borrowings that were retained in the dialect were frequently used words, such as foods (birog, bliny, arbus, kalatsch), buildings or sights around the house (ambar, nuzhnik, grilitz, sa(i)rai, schtepp), and frequently used borrowings such as sa(i)rai (mess) and gum (pal).

On the example of borrowing history of this particular dialect once spoken in a relatively closed community one can observe how fast words disappear or are being replaced by new loans in a relatively short period of time.

\section{REFERENCES}

Henry BENDER, 1913: The First Settlement of German Russian colonists from the Volga River, Russia. Russell Record, August 23. http://www.berschauer.com/Genealogy/ Accounts/Henry_Bender.html

Nina BEREND and Hugo JEDIG, 1991: Deutsche Mundarten in der Sowjetunion: Geschichte der Erforschung und Bibliographie. Marburg: N. G. Elwert.

--, 2003: Zur Vergleichbarkeit von Sprachkontakten: Erfahrungen aus wolgadeutschen Sprachinseln in USA und Russland. German Language Varieties Worldwide: Internal and external Perspectives. Eds. William D. Keel and Klaus J. Mattheier. New York, Berlin, Bern, Frankfurt am Main: Peter Lang. 239-268.

H. H. BIELFELDT, 1965: Die Entlehnungen aus den verschiedenen slawischen Sprachen im Wortschatz derneuhochdeutschen Schriftsprache. Sitzungsberichte der Deutschen Akademie der Wissenschaften Berlin, Klasse für Sprache, Literatur und Kunst, 1, 1-59.

Rogier Philip Charles Eduard BLOKLAND, 2005: The Russian Loanwords in Literary Estonian. Diss. University of Groningen. 2005. Web 4. Nov 2009. http://dissertations. ub.rug.nl/faculties/arts/2005/r.p.c.e.blokland/

${ }^{10}$ Six informants were born in the 1920s (1924-1926). Two others were born in 1917 and 1934, respectively. 
J. Neale CARMAN, 1962: Foreign-Language Units in Kansas I. Historical Atlas and Statistics. Lawrence: University of Kansas Press.

Jakob and Wilhelm GRIMM (eds.), 1854: Deutsches Wörterbuch. Leipzig.

Viktor HEINZ, 2006: Über Eigentümlichkeiten des Wolgadeutschen Wortschatzes. Jahrbuch für Internationale Germanistik 2, 137-149.

Chris D. JOHNSON, 1994: The Volga German Dialect of Schoenchen, Kansas. Diss. University of Kansas.

Slawomira KALETA, 1999: Entlehnungen aus dem Polnischen in deutschsprachigen Urkunden der Krakauer Kanzlei des 14.-16. Jahrhunderts. Vielfalt der Sprachen. Festschrift für Aleksander Szulc zum 75. Geburtstag. Eds. Maria Klanska and Peter Wiesinger. Wien. 63-86.

William KEEL, 1981: On Dialect Mixture: The Case of Ellis County (Kansas) Volga German. Proceedings of the Mid-America Linguistics Conference. Ed. T. Benett-Kastor. Wichita. 320-335.

- -, 1982: On the 'Heimatbestimmung' of the Ellis County (Kansas) Volga-German Dialects. Yearbook of German-American Studies 17, 99-109.

--, 1989: Deutsche Mundarten in Kansas: Sprachatlas der wolgadeutschen Mundarten. Sprachatlanten des Deutschen: Laufende Projekte. Eds. Werner H. Veith and Wolfgang Putschke. Tübingen: Max Niemeyer Verlag. 387-399.

Valentin KIPARSKY, 1936: Fremdes im Baltendeutsch. Helsinki.

Rev. Francis S LAING, 1910: German-Russian Settlements in Ellis County, Kansas. Collections of the Kansas State Historical Society 11, 489-528.

Igor PLEVE, 1998: Nemeckie kolonii na Volge vo 2-oj polovine XVIII veka. Moscow: Gothika.

J. C. RUPPENTHAL, 1913: The German Element in Central Kansas. Kansas Historical Collections 13, 513-533.

--, 1914: Russian Words in Kansas. Dialect Notes 4.2. Ed. George Davis Chase. 161-162.

Richard SALLET, 1931: Russlanddeutsche Siedlungen in den Vereinigten Staaten von Amerika. Deutsch-amerikanische Geschichtsblätter. German-American Historical Review; Jahrbuch der Deutsch-amerikanischen historischen Gesellschaft von Illinois 31, 5-126.

Max VASMER (= Maks FASMER), 1986: Ètimologičeskij slovar' russkogo jazyka. Moscow: Progress.

G. WIENS, 1957: Entlehnungen aus dem Russischen im Niederdeutschen der Mennoniten in Rußland. Niederdeutsches Jahrbuch 93.

Renate WINTER, 1961: Einige slawische Entlehnungen in den niederdeutschen Mundarten des ehemaligen Hinterpommern. Wissenschaftliche Zeitschrift der Wilhelm-PieckUniversität Rostock. Gesellschafts- und sprachwissenschaftliche Reihe 10, 271-277. 


\section{RUSKE IZPOSOJENKE V NEMŠKEM NAREČJU OB VOLGI V OKRAJU RUSSEL, KANZAS}

Članek analizira besede, ki so jih v raziskovanju nemških narečij ob Volgi v Kanzasu tradicionalno obravnavali kot ruske izposojenke, predstavlja razpravo o njihovi vprašljivi etimologiji in se sprašuje, ali so nekatere izmed teh besed bile poznane narečnim govorcem že pred prihodom v Rusijo.

Primerjava ruskih izposojenk v milibergerškem narečju s podatki o ruskih izposojenkah baltskih Nemcev kaže, da so priseljenci lahko nekatere besede, ki jih najdemo v Kanzasu, prevzeli iz ruščine ali drugih slovanskih jezikov že pred preselitvijo v Kanzas - razprava je odkrila, da so bile nekatere besede znane tudi v drugih delih Nemčije že pred osemnajstim stoletjem, vendar pa pomanjkanje jezikovnih podatkov o zgodaj prevzetih besedah v nemških narečjih ne dopušča dokončnega zaključka. Opravljeno terensko delo in intervjuji so pokazali, da je razširjenost nekaterih prevzetih besed v zaprti skupnosti neenakomerna - informatorka je omenila, da je izraz trosti uporabljala le njena stara mati, bratranec pa jo je dopolnil, da njegovi prijatelji to besedo poznajo in jo med pogovori tudi uporabljajo. Analizirani podatki kažejo, da je zadnja, najmlajša generacija govorcev ohranila zelo malo število ruskih besed. Mnogih besed, ki so se v besedišču prednikov še ohranile kot prevzete ruske besede, informatorji niso več poznali, saj so jih nadomestili z angleškimi ustreznicami. 